\title{
Effects of High and Low Sodium Diet on Blood Pressure and Heart Rate in Mice Lacking the Functional Grainyhead-Like 1 Gene
}

\author{
A. WALKOWSKA ${ }^{1}$, M. PAWLAK ${ }^{2}$, S. M. JANE ${ }^{3,4}$, E. KOMPANOWSKA-JEZIERSKA ${ }^{1}$, \\ T. WILANOWSKI ${ }^{2}$
}

${ }^{1}$ Department of Renal and Body Fluid Physiology, Mossakowski Medical Research Center, Polish Academy of Sciences, Warsaw, Poland, ${ }^{2}$ Laboratory of Signal Transduction, Nencki Institute of Experimental Biology, Polish Academy of Sciences, Warsaw, Poland, ${ }^{3}$ Department of Medicine, Monash University Central Clinical School, Prahran VIC, Australia, ${ }^{4}$ Alfred Hospital, Prahran VIC, Australia

Received January 20, 2016

Accepted June 6, 2016

On-line October 26, 2016

\begin{abstract}
Summary
Hypertension is a major health problem throughout the world because of its high prevalence and its association with increased risk of cardiovascular disease. Two independent studies discovered a locus conferring susceptibility to essential hypertension on chromosome 2, in the 2 p25 region, but the causative gene remains unknown. Grainyhead-like 1 ( GRHL1) is one of the genes located in this region. Our experiments determined that the Grh/1-null mice, when fed standard diet, have the same blood pressure as their wild type littermate controls. However, we discovered that blood pressure of these mice increases following high sodium diet and decreases when they are fed low sodium diet, and similar effects were not observed in the control wild type littermates. This suggests that the Grhl1-null mice are sensitive to the development of salt-sensitive hypertension. Thus it is possible that the GRHL1 gene is involved in the regulation of blood pressure, and it may be the causative gene for the locus of susceptibility to essential hypertension in the $2 \mathrm{p} 25$ region.
\end{abstract}

\section{Key words}

Blood pressure $\bullet$ Heart rate $\bullet$ Genetics $\bullet$ Transcription factors $\bullet$ GRHL1

\section{Corresponding author}

T. Wilanowski, Laboratory of Signal Transduction, Nencki Institute of Experimental Biology, Polish Academy of Sciences, 3 Pasteur St., 02-093 Warsaw, Poland. Fax: +48 225892533. E-mail: t.wilanowski@nencki.gov.pl
There is extensive evidence suggesting a major genetic impact on blood pressure regulation and development of hypertension (Padmanabhan et al. 2015). Two independent studies reported a locus of susceptibility to essential hypertension - HYT3 (hypertension, essential, susceptibility to, 3 ) - at the chromosomal location $2 \mathrm{p} 25$, but the causative gene was never identified (Angius et al. 2002, Zhu et al. 2001). The Grainyhead-like 1 (GRHL1) gene is located in this chromosomal region, and there are data suggesting that GRHL1 may be involved in the regulation of blood pressure. GRHL1 is highly expressed in the kidney (Pawlak et al. 2015), and kidney malfunctions often cause hypertension (Messerli et al. 2007). Furthermore, some other genes from the Grainyhead-like family are involved in blood pressure regulation (Koutnikova et al. 2009, Yamaguchi et al. 2006). Recently we described the effects of loss of the Grhll gene for gene expression in the kidneys, blood pressure and heart rate in a mouse model (Pawlak et al. 2015). Those experiments uncovered numerous abnormalities in renal gene expression, but the results of blood pressure measurements were inconclusive. Since sensitivity of blood pressure to dietary sodium intake is associated with hypertension in human subjects (Weinberger et al. 1986), we decided to measure blood pressure in Grhll-null mice fed with high and low sodium diet.

In our experiments we used the Grhll "knock- 
out" mouse strain (Wilanowski et al. 2008). The genetic background is C57BL/6 (Black 6). In all our experiments we used only male mice, in order to avoid blood pressure variations caused by the menstrual cycle in females. Experimental animals were fed either high $(4 \% \mathrm{Na})$ or low $(0.15 \% \mathrm{Na})$ sodium diet (w/w, ssniff GmbH, Soest, Germany). Standard diet contained $0.25 \% \mathrm{Na}$ (w/w, ssniff GmbH, Soest, Germany).

The measuring of blood pressure and heart rate in conscious mice using tail-cuff method were performed as described previously (Pawlak et al. 2015). Systolic, mean and diastolic blood pressure and heart rate were measured during three to four consecutive days using tail-cuff method (CODA System, Kent Scientific Corporation, Torrington, CT, USA). During the three days before the start of experimental measurements animals were accustomed to the restrainment needed for measurement. In each experiment, six mice per genotype were used. We applied the following experimental protocol: 1) standard diet followed by blood pressure measurements; 2) three weeks of low sodium diet followed by blood pressure measurements; 3 ) three weeks of standard diet followed by blood pressure measurements; 4) three weeks of high sodium diet followed by blood pressure measurements. The significance of changes was evaluated by multivariate analysis of variance (ANOVA) with repeated measurements, followed by Duncan's post-hoc test. Heart rate data did not meet the assumption of normality and homogeneity of variance, thus non-parametric Friedman test was used to analyze the statistical differences (STATISTICA, version 10.0, StatSoft Inc.).

This study was carried out in strict accordance with the regulations of the Experiments on Animals Act (Act of 21 January 2005 on experiments on live animals, the Parliament of the Republic of Poland, Dz. U. Nr 33, poz. 289); as well as with the Directive 2010/63/EU of the European Parliament and of the Council of the European Union of 22 September 2010 on the protection of animals used for scientific purposes. All animal experiments were approved by the First Warsaw Local Ethics Committee for Animal Experimentation (permit number 28/2010) and by the Fourth Warsaw Local Ethics Committee for Animal Experimentation (permit number 66/2012). All efforts were made to minimize suffering.

The values of blood pressure are shown in

Fig. 1. Systolic blood pressure was significantly higher in

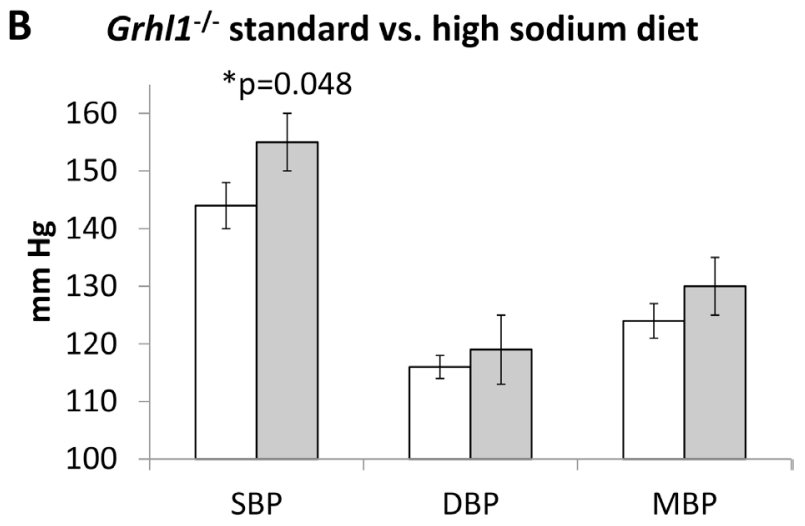

D Grhl1\% standard vs. low sodium diet

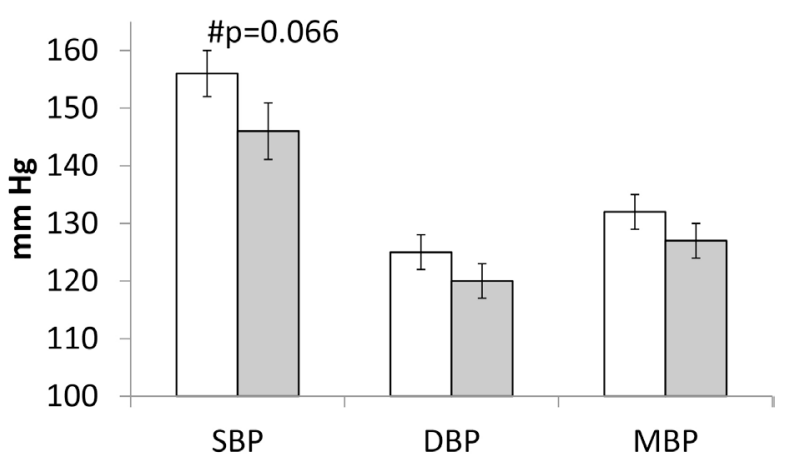

Fig. 1. Blood pressure in Grh/1-null and control mice. In all diagrams, measurements following feeding with standard diet are indicated by open bars, and following either high $(\mathbf{A}, \mathbf{B})$ or low $(\mathbf{C}, \mathbf{D})$ sodium diet - by shaded bars. SBP - systolic blood pressure, DBP - diastolic blood pressure, MBP - mean blood pressure. Measurement units on vertical axes are $\mathrm{mm} \mathrm{Hg} \pm$ standard error. $\mathrm{p}$ values were calculated using ANOVA with repeated measurements, followed by Duncan's post-hoc test. $p$ values $<0.1$ are indicated above diagrams. 
the Grhll-null mice following high sodium diet, in comparison with earlier measurements in the same mice fed with standard diet. We also observed a decrease in systolic blood pressure in $\mathrm{Grhl}^{-/-}$mice following low sodium diet, which was close to significant $(\mathrm{p}=0.066)$. In control mice, blood pressure was similar regardless of the feed. There is discrepancy in the literature regarding the sensitivity of C57BL/6 mice (genetic background of Grhl1 "knock-out" line) to the development of salt-sensitive hypertension, with different studies reporting contradictory findings. Our results are consistent with the notion that the blood pressure of C57BL/6 mice remains similar irrespective of them being fed standard, low or high sodium feed (Zhang et al. 2015). Heart rate was not significantly changed following either high or low sodium diet, in the Grhll-null mice or in the wild type littermate controls (data not shown).

In conclusion, the present study showed that there are statistically significant changes in blood pressure following high and low sodium diet in the $\mathrm{Grhl1}^{-/-}$mice, in comparison with their $\mathrm{Grhl1}^{+/+}$littermate controls. This suggests that the loss of Grhll gene affects blood pressure regulation in conditions related with either excess or deficit of sodium intake, which may imply an alteration in sodium transport leading to salt sensitivity. Alternatively, loss of Grhll may impair the functioning of sympathetic nervous system or of baroreceptors. These hypotheses will require further studies.

\section{Conflict of Interest}

There is no conflict of interest.

\section{Acknowledgements}

We thank Olga Gawrys for help in statistical analyses. This study was supported by the project grant 2011/03/B/NZ1/00148 awarded by the National Science Centre of Poland.

\section{References}

ANGIUS A, PETRETTO E, MAESTRALE GB, FORABOSCO P, CASU G, PIRAS D, FANCIULLI M, FALCHI M, MELIS PM, PALERMO M, PIRASTU M: A new essential hypertension susceptibility locus on chromosome 2p24-p25, detected by genomewide search. Am J Hum Genet 71: 893-905, 2002.

KOUTNIKOVA H, LAAKSO M, LU L, COMBE R, PAANANEN J, KUULASMAA T, KUUSISTO J, HARING HU, HANSEN T, PEDERSEN O, SMITH U, HANEFELD M, WILLIAMS RW, AUWERX J: Identification of the UBP1 locus as a critical blood pressure determinant using a combination of mouse and human genetics. PLoS Genet 5: e1000591, 2009.

MESSERLI FH, WILLIAMS B, RITZ E: Essential hypertension. Lancet 370: 591-603, 2007.

PADMANABHAN S, CAULFIELD M, DOMINICZAK AF: Genetic and molecular aspects of hypertension. Circ Res 116: 937-959, 2015.

PAWLAK M, WALKOWSKA A, MLACKI M, PISTOLIC J, WRZESINSKI T, BENES V, JANE SM, WESOLY J, KOMPANOWSKA-JEZIERSKA E, WILANOWSKI T: Consequences of the loss of the Grainyhead-like 1 gene for renal gene expression, regulation of blood pressure and heart rate in a mouse model. Acta Biochim Pol 62: 287-296, 2015.

WEINBERGER MH, MILLER JZ, LUFT FC, GRIM CE, FINEBERG NS: Definitions and characteristics of sodium sensitivity and blood pressure resistance. Hypertension 8: II127-II134, 1986.

WILANOWSKI T, CADDY J, TING SB, HISLOP NR, CERRUTI L, AUDEN A, ZHAO LL, ASQUITH S, ELLIS S, SINCLAIR R, CUNNINGHAM JM, JANE SM: Perturbed desmosomal cadherin expression in grainy head-like 1-null mice. EMBO J 27: 886-897, 2008.

YAMAGUCHI Y, YONEMURA S, TAKADA S: Grainyhead-related transcription factor is required for duct maturation in the salivary gland and the kidney of the mouse. Development 133: 4737-4748, 2006.

ZHANG MZ, YAO B, WANG Y, YANG S, WANG S, FAN X, HARRIS RC: Inhibition of cyclooxygenase-2 in hematopoietic cells results in salt-sensitive hypertension. J Clin Invest 125: 4281-4294, 2015.

ZHU DL, WANG HY, XIONG MM, HE X, CHU SL, JIN L, WANG GL, YUAN WT, ZHAO GS, BOERWINKLE E, HUANG W: Linkage of hypertension to chromosome 2q14-q23 in Chinese families. $J$ Hypertens 19: 55-61, 2001. 